\title{
Polska i jej opinia publiczna wobec konfliktu w Bośni i Hercegowinie i jego następstw
}

Ostatnia dekada XX w. w Europie Środkowo-Wschodniej to czas przemian, określanych mianem „Jesieni Narodów”. Proces rozpoczęty w Polsce obradami „okragłego stołu” (luty-kwiecień 1989 r.) ${ }^{1}$ doprowadził do obalenia rządów komunistycznych w tej części kontynentu, do demontażu bloku wschodniego, a w konsekwencji do rozpadu ukształtowanego po II wojnie światowej „ładu jałtańskiego". W większości przypadków przebiegał łagodnie, np. w Polsce, w Czechosłowacji, na Węgrzech. Jedynie w Rumunii przybrał charakter krwawej rozprawy. Nikt nie spodziewał się jednak, że zmiany zapoczątkowane jesienią 1989 r. przyspieszą upadek Socjalistycznej Federacyjnej Republiki Jugosławii (SFRJ) ${ }^{2}$.

Celem niniejszego szkicu jest przedstawienie reakcji naczelnych organów władzy Rzeczpospolitej Polskiej (RP) i polskiej opinii publicznej na wybuch i przebieg wojny w Bośni i Hercegowinie w latach 1992-1995. Tekst został podzielony na dwie części. W pierwszej omówiono działania podejmowane przez Sejm, Prezydenta RP i Radę Ministrów ${ }^{3}$. Chcąc uniknąć powielenia powszechnie znanych faktów, skupiono się na zależności aktywności polskiej dyplomacji na Bałkanach od priorytetów polskiej polityki zagranicznej, tj. wyboru i realizacji opcji prozachodniej w możliwych do urzeczywistnienia obszarach. Skupiono również uwagę na kwestii influencji wspomnianego konfliktu na politykę wewnętrzna. W części drugiej zaprezentowano stanowisko polskiej opinii publicznej w odniesieniu do zagadnień związanych bezpośrednio lub pośrednio z wojną na obszarze postjugosłowiańskim, podjętych w części pierwszej.

1 J. Wiatr, Polska droga do demokracji, [w:] J. Wiatr, J. Raciborski, J. Bartkowski, B. Frątczak-Rudnicka, J. Kilias, Demokracja polska 1989-2003, Warszawa 2003, s. 13-56.

2 Wśród przyczyn zewnetrznych, determinujacych rozpad Jugosławii, czołowe miejsce zajmuje upadek rządów komunistycznych w krajach Europy Środkowo-Wschodniej.

${ }^{3}$ Wojna w Bośni i Hercegowinie przypada w Polsce na prezydenturę Lecha Wałęsy oraz działalność Sejmu I (1991-1993) i II (1993-1997) kadencji. We wspomnianym czasie władzę sprawowały gabinety: Jana Olszewskiego (6 XII 1991-5 VI 1992); Hanny Suchockiej (7 VII 1992-18 X 1993); Waldemara Pawlaka (18 X 1993-1 III 1995); Józefa Oleksego (6 III 1995-26 I 1996). Funkcję ministra spraw zagranicznych sprawowali zaś: Krzysztof Skubiszewski (13 IX 1989-25 X 1993); Andrzej Olechowski (25 X 1993-6 III 1995); Władysław Bartoszewski (6 III 1995-XII 1995). 
Forma, jak również zakres opracowania zdeterminował dobór źródeł. Bibliografia części pierwszej obejmuje m.in. materiały Biura Analiz Sejmowych, sprawozdania stenograficzne z posiedzeń Sejmu I i II kadencji, opracowania dokumentów ${ }^{4}$ oraz podstawową literaturę przedmiotu ${ }^{5}$. Część druga została przygotowana na podstawie analiz badań opinii publicznej przeprowadzonych przez Ośrodek Badań Opinii Publicznej (OBOP) w latach 1991-1998 oraz kwerendę ogólnopolskich dzienników o charakterze społeczno-politycznym: „Rzeczpospolitej” i „Gazety Wyborczej”. Bardzo pomocne okazały się wypowiedzi Tadeusza Mazowieckiego ${ }^{6}$, jak również kontrowersyjne ujęcie konfliktu przez Marka Waldenberga ${ }^{7}$, dla których uzupełnieniem był cykl reportaży Ryszarda Bilskiego z jego podróży po Bałkanach ${ }^{8}$.

Społeczeństwo i państwo polskie skupione w I połowie lat 90. XX w. na problemach związanych $\mathrm{z}$ transformacją ustrojową i kształtowaniem poprawnych stosunków z sąiadami, nie mogło pozostać obojętne na wydarzenia rozgrywające się na terenie byłej Jugosławii. Wynikało to z ówczesnych założeń polskiej polityki zagranicznej. Czołowe miejsce, obok pogłębienia procesu demokratyzacji i tworzenia instrumentów gospodarki wolnorynkowej, zajmowało wzmocnienie prestiżu i pozycji państwa, m.in. przez aktywne działanie w organizacjach międzynarodowych, współtworzenie europejskiego systemu bezpieczeństwa ${ }^{9}$. Nie pozwalało to na indyferentność wobec tragedii bałkańskiej. W dużej mierze priorytety polskiej polityki zagranicznej, na czele których umiejscowiono integrację Polski z instytucjami europejskimi i euroatlantyckimi ${ }^{10}$, zdeterminowały aktywność i sposób reakcji polskiej dyplomacji na wydarzenia na Bałkanach.

${ }^{4}$ Najbardziej przydatne okazały się: K. Skubiszewski, Polityka zagraniczna $i$ odzyskanie niepodległości - przemówienia oświadczenia wywiady 1989-1993. Warszawa 1997; Raporty Tadeusza Mazowieckiego z bytej Jugosławii, Poznań-Warszawa 1993.

${ }^{5}$ R. Podgórzańska, Działalność Sejmowej Komisji Spraw Zagranicznych (1989-2005). Wybrane problemy, Warszawa 2007; R. Kuźniar, Droga do wolności. Polityka zagraniczna III Rzeczypospolitej, Warszawa 2008.

6 T. Mazowiecki, Źródła dramatu - wyzwania przyszłości, [w:] Węzeł batkański, red. J. Piekło, S. Wilkanowicz, Kraków 1999

${ }^{7}$ M. Waldenberg, Rozbicie Jugosławii. Jugosłowianskie lustro międzynarodowej polityki, Warszawa 2005

${ }^{8}$ R. Bilski, Kocioł batkański, Warszawa 2000.

${ }^{9}$ Zob. Informacja ministra spraw zagranicznych o polityce zagranicznej Rzeczypospolitej Polskiej w 1990 r., [w:] Sejm RP. X kadencja. Sprawozdanie stenograficzne z 28 posiedzenia Sejmu RP $w$ dniach 26, 27, 28 kwietnia 1990 roku, Warszawa 1990; Expose sejmowe ministra spraw zagranicznych RP, Krzysztofa Skubiszewskiego, „Zbiór Dokumentów” [PISM] 1990, $\mathrm{nr} 2$.

${ }_{10}$ Po raz pierwszy, publicznie wyartykułował akces Polski do zachodnich struktur minister spraw zagranicznych Krzysztof Skubiszewski, w exposé wygłoszonym w Sejmie 8 maja 1992 r., postulując: „ugruntowanie europejskiej orientacji Polski przez stopniowe właczanie jej do struktur zachodnioeuropejskich i północnoatlantyckich" - Informacja ministra spraw zagranicznych o polityce zagranicznej Rzeczypospolitej Polskiej, [w:] Sejm 
Władze polskie szybko uznały niepodległość Słowenii, Chorwacji11 , a następnie Bośni i Hercegowiny, nawiązując z nimi stosunki dyplomatyczne i gospodar$\mathrm{cze}^{12}$. Uznanie prawno-międzynarodowe sugerowało, że polskie elity władzy oceniaja wydarzenia, wyciagaja $\mathrm{z}$ nich wnioski i podejmują działania analogiczne do rządów krajów zachodnioeuropejskich. Sa w tym samym stopniu europejskie, demokratyczne, dojrzałe i odpowiedzialne. Mogło to pozytywnie wpłynać m.in. na budowane $\mathrm{z}$ trudem stosunki niemiecko-polskie oraz poprawić, za sprawa hierarchów polskiego Kościoła, wizerunek obozu rządzącego w oczach katolickich wyborców. Innymi słowy, w tamtym czasie, Polska nie mogła sobie pozwolić na luksus odmienności wobec wspólnoty, której poparcia potrzebowała, do której chciała przynależeć i zajmować w niej określoną pozycję ${ }^{13}$.

W początkowej fazie wojny polskie władze bez zastrzeżeń popierały posunięcia społeczności międzynarodowej. Akceptacja wynikała z faktu, iż podejmowane działania miały zapobiec rozprzestrzenieniu się konfliktu na obszary sasiadujących z Bośnią i Hercegowina państw. Wiara w skuteczność takich organizacji, jak ONZ, KBWE, a przede wszystkim idealizowanej Wspólnoty Europejskiej, była bardzo duża ${ }^{14}$. Wątpliwości pojawiły się w 1992 r. w związku z raportami

RP. I kadencja. Sprawozdanie stenograficzne z 14 posiedzenia Sejmu RP, 8 maja 1992, Warszawa 1992, s. 152.

${ }_{11}$ Zob. Uchwała Rady Ministrów RP nr 4/92 (w sprawie uznania przez Rzeczpospolita Polska Republiki Stowenii i Republiki Chorwacji) - Warszawa, 21 stycznia 1992 r., "Zbiór Dokumentów" [PISM] 1992, nr 1.

12 Zob.: Porozumienie $w$ drodze wymiany not między Ministrem Spraw Zagranicznych $R P$ i Ministerstwem Spraw Zagranicznych Republiki Stowenii o nawiazaniu stosunków dyplomatycznych między Rzeczpospolita Polska a Republika Stowenii - Warszawa, Ljubljana, 10 kwietnia 1992 r., „Zbiór Dokumentów” [PISM] 1992, nr 2; Umowa między rzadem Rzeczypospolitej Polskiej a rzadem Republiki Stowenii o wspótpracy gospodarczej Warszawa, 29 października 1992 r., „Zbiór Dokumentów” [PISM] 1993, nr 3; Umowa między rzqdem Rzeczypospolitej Polskiej a rzqdem Republiki Chorwacji o wspótpracy gospodarczej - Warszawa, 5 listopada 1992 r., „Zbiór Dokumentów” [PISM] 1994, nr 2.

${ }^{13}$ Należy podkreślić, że w początkach lat 90 . XX w. to kraje Europy Zachodniej i organizacje europejskie postrzegane były przez polskich polityków jako realni sprzymierzeńcy. W wystapieniach premierów III RP i ministra spraw zagranicznych K. Skubiszewskiego współpraca z nimi usytuowana jest zdecydowanie przed kontaktami ze Stanami Zjednoczonymi.

$14 \mathrm{~W}$ dużej mierze wynikało to $\mathrm{z}$ dominującej roli, jaką te organizacje odgrywały w zażegnaniu konfliktu na terenie byłej Jugosławii do końca 1994 r., zanim inicjatywy nie przejeli za pośrednictwem NATO Amerykanie - J. Kiwerska, Swiat w latach 1989-2004. Wydarzenia - konflikty - procesy, Poznań 2005, s. 89-96; taż, Problemy partnerstwa transatlantyckiego, seria: „Zeszyty Instytutu Zachodniego”, nr 22/2001, s. 10. Ponadto wiązało się z promowana w Polsce, m.in. przez K. Skubiszewskiego, koncepcja bezpieczeństwa zbiorowego pod egidą ONZ oraz bezpieczeństwa regionalnego. W ramach tychże rozważano pod wpływem konfliktu jugosłowiańskiego możliwość autoryzowania przez KBWE operacji pokojowych „peacekeeping” - K. Skubiszewski, Polityka europejska państwa polskiego w latach dziewięćdziesiatych. Przemówienie wygłoszone w Senacie RP w dniu 25 czerwca 1992 r., [w:] tenże, Polityka zagraniczna..., s. 244. Zob. także A. Piątkowska, KBWE/OBWE w polskiej 
specjalnego sprawozdawcy genewskiej Komisji Praw Człowieka ONZ T. Mazowieckiego o łamaniu praw człowieka na terenach objętych walkami i ostatecznie jego decyzja o rezygnacji z pełnionej funkcji (w 1995 r. $)^{15}$. Powściagliwość strony polskiej wynikała również $\mathrm{z}$ niepowodzeń kolejnych rozmów pokojowych, zwiększonych oczekiwań Wspólnoty Europejskiej wobec krajów Europy Środkowej, przy ich równoczesnym kunktatorstwie. Na przykład, kwestią budzaca niepokój Polski było rozszerzenie 4 czerwca 1992 r. mandatu UNPROFOR na teren Bośni i Hercegowiny, celem ochrony lotniska w Sarajewie i konwojów humanitarnych ${ }^{16}$. Polskie Ministerstwo Spraw Zagranicznych uznało, że polscy żołnierze stacjonujacy w Chorwacji (Krajina) nie są przygotowani do działań wykraczajacych ponad dotychczasowy mandat $\mathrm{ONZ}^{17}$, zaś jego rozszerzenie spowoduje niewatpliwie wzrost bezpośredniego zagrożenia dla zdrowia i życia żołnierzy. Sprawa powróciła ponownie, kiedy 6 maja 1993 r., na mocy rezolucji Rady Bezpieczeństwa ONZ, utworzono sześć „stref bezpieczeństwa”, które miały być chronione przez „błękitne hełmy”, i które w razie bezpośredniego zagrożenia mogły użyć broni. Okazało się wtedy, że najbardziej zaangażowane kraje zachodnioeuropejskie nie zamierzały narażać swych żołnierzy na takie niebezpieczeństwo, zrzucajac ciężar na barki innych ${ }^{18}$. Strona polska wyraziła również swój sprzeciw wobec amerykańskiej propozycji zniesienia embarga na dostawy broni dla Muzułmanów (maj 1993 r.) stwierdzajac, że przyczyniłoby się to do dalszej proliferacji konfliktu ${ }^{19}$. Oficjalnie władze polskie nie zdobyły się jednak na

polityce zagranicznej, [w:] Polityka zagraniczna RP 1989-2002, red. nauk. R. Kuźniar, K. Szczepanik, Warszawa 2003.

${ }_{15} \mathrm{~W}$ polskiej prasie po raz pierwszy fragmenty raportów T. Mazowieckiego z byłej Jugosławii pojawiły się w „Gazecie Wyborczej” już 31 sierpnia $1992 \mathrm{r}$. Były też publikowane w „Rzeczpospolitej”, w rubryce „Swiat” (m.in.: Chorwacja odrzuca raport Mazowieckiego z 13 października 1993 r.; Groźba eksterminacji Muzułmanów z 10 grudnia 1993 r.; Belgrad oskarża Mazowieckiego z 24 marca 1995 r.; Serbskie dzieci przymuszane do chorwackiego hymnu z 12 lipca 1995 r.). Mazowiecki złożył rezygnację z pełnionej funkcji 27 lipca 1995 r., jako wyraz protestu m.in. wobec tragedii w Srebrenicy.

${ }_{16}$ Według danych ONZ z 30 kwietnia 1994 r., w działaniach UNPROFOR uczestniczyło 29 policjantów cywilnych, 984 żołnierzy i 23 obserwatorów wojskowych z Polski. Spośród siedmiu misji pokojowych, w których Polska wówczas uczestniczyła z ramienia ONZ, misja UNPROFOR była reprezentowana najliczniej - L. Łukaszczuk, Polska w Organizacji Narodów Zjednoczonych, [w:] Polska w organizacjach międzynarodowych, red. S. Parzymies, I. Popiuk-Rysińska, Warszawa 2001, s. 60.

17 A. Orzelska, Polska polityka zagraniczna wobec rozbieżności w stosunkach transatlantyckich na tle konfliktów w bytej Jugostawii, „Studia Polityczne” 2009, nr 24, s. 234.

${ }_{18}^{18}$ I tak np. w Republice Federalnej Niemiec (która wg niektórych walnie przyczyniła sie do uruchomienia machiny wojennej w byłej Jugosławii), Federalny Trybunał Konstytucyjny dopiero 12 lipca $1994 \mathrm{r}$. wydał orzeczenie, na mocy którego możliwy był udział żołnierzy niemieckich $\mathrm{w}$ akcjach zbrojnych poza obszarem Niemiec i NATO (out of area) J. Kiwerska, Stosunki niemiecko-amerykańskie (1992-2002), seria: „Zeszyty Instytutu Zachodniego", nr 32/2003, s. 9.

${ }^{19}$ A. Orzelska, $d z$. cyt., s. 234. 
krytykę podejmowanych w związku z wojną w Bośni i Hercegowinie działań i przyjęły z ulga z trudem wypracowany i niedoskonały kompromis, jakim był układ pokojowy z Dayton.

Polska popierała i uczestniczyła w działaniach wspólnoty międzynarodowej. Czyniła to, zgodnie z przyjętymi założeniami, za pośrednictwem istniejących organizacji międzynarodowych. Panujący pogląd, że udział naszego kraju w rozwiązaniu konfliktu na terenie Bośni i Hercegowiny był niewielki, jest bardzo krzywdzący ${ }^{20}$. Jako kraj postkomunistyczny, owładnięty poważnym kryzysem gospodarczym, III Rzeczpospolita nie dysponowała ani odpowiednimi kadrami, ani funduszami umożliwiającymi bardziej dynamiczne działania (wydatki Ministerstwa Spraw Zagranicznych przewyższały kwoty przewidziane w budżecie państwa w poszczególnych latach) ${ }^{21}$. Ponadto Polska nie miała szczególnie żywotnych interesów w odległej Jugosławii. Aktywność Polski na tym terenie, w porównaniu z państwami zachodnimi, można uznać za skromna. Należy jednak pamiętać, że w owym czasie nasz kraj dopiero pracował na silną pozycję międzynarodowa i nie powinno się porównywać czynionych przez niego starań z działaniami Niemiec, Francji, Wielkiej Brytanii czy też Rosji. Można to czynić tylko w odniesieniu do państw Europy Środkowo-Wschodniej, wśród których Polska coraz częściej odgrywała rolę lidera, dzięki m.in. Grupie Wyszehradzkiej czy też Inicjatywie Środkowoeuropejskiej.

O wiele ważniejszy od oddziaływania na wydarzenia w Bośni i Hercegowinie był wpływ toczącego się konfliktu na politykę wewnętrzną Polski. Wojna w byłej Jugosławii przyczyniła się do uświadomienia polskiej elicie władzy, jaka perspektywa czeka państwo, które $\mathrm{w}$ porę nie dostrzeże i nie upora się $\mathrm{z}$ problemami, pojawiającymi się w procesie transformacji ustrojowej, ale również ze zmianami zachodzącymi we współczesnym świecie. Wydarzenia rozgrywające się na Bałkanach w latach 1992-1995 wpłynęły pośrednio na wypracowanie polityki bezpieczeństwa i strategii obronnej, uregulowanie coraz bardziej palącego problemu uchodźców, imigrantów, mniejszości narodowych i etnicznych, przypieczętowały prozachodnią opcję rozwoju.

W momencie wybuchu konfliktu zbrojnego w Bośni i Hercegowinie, polska dyplomacja, jak to określił minister spraw zagranicznych K. Skubiszewski, była na etapie, w którym „Sojusz [Atlantycki] i Polska dochodziły do wspólnego poglądu, iż nasz region, a specjalnie Polska, winny być objęte ochronnym

${ }^{20}$ Zdaniem T. Mazowieckiego: „Polska nie wykorzystała swoich możliwości” - zob. T. Mazowiecki, $d z$. cyt., s. 22. Zupełnie odmiennego zdania o zaangażowaniu Polski na terenie byłej Jugosławii w latach 90. XX w. jest Jan Tombiński - por. J. Tombiński, Udziat Polski w realizacji programu Paktu Stabilności dla Europy Potudniowo-Wschodniej, [w:] Ogniska konfliktów: Bałkany, Kaukaz, red. B. Klich, Kraków 2000, s. 12-13.

${ }_{21}$ R. Podgórzańska, dz. cyt., s. 158-180. 
wpływem Sojuszu”22. Od grudnia 1991 r. Polska aktywnie uczestniczyła w pracach Północnoatlantyckiej Rady Współpracy, jednak nie artykułowała oficjalnie chęci przystapienia do Sojuszu. Było to uzależnione od stanowiska Stanów Zjednoczonych i w ograniczonym stopniu od europejskich sojuszników, np. Niemiec. Wydaje się, że sposób zaangażowania Polski na terenie byłej Jugosławii, a właściwie brak rażących błędów w postaci sprzeciwu wobec działań podejmowanych przez wspólnotę międzynarodowa, pewnego rodzaju bezkrytyczność, przyczyniły się do pozytywnego postrzegania naszego kraju jako potencjalnego partnera Sojuszu. Pozwoliło to na oficjalne zasygnalizowanie dążeń do członkostwa w Pakcie. W corocznym exposé na temat polityki zagranicznej w Sejmie 8 maja $1992 \mathrm{r}$. Skubiszewski publicznie zapowiedział, iż celem Polski jest „stopniowe i faktyczne włączanie Polski w system bezpieczeństwa Sojuszu. Członkostwo jest celem perspektywicznym" ${ }^{23}$. W grudniu 1992 r. udał się wraz z innymi ministrami spraw zagranicznych krajów Inicjatywy Środkowoeuropejskiej do Waszyngtonu, by oficjalnie przedstawić propozycję interwencji wojskowej na terenie Bośni i Hercegowiny. Misja zakończyła się porażka, ale z punktu widzenia polskiej racji stanu minister Skubiszewski odniósł sukces. 18 grudnia 1992 r. w rozmowie z sekretarzem stanu USA Lawrancem Eagleburgerem i amerykańskim ambasadorem przy NATO Reginaldem Bartholomewem wspomniał o „potrzebie integracji Polski z NATO oraz poszerzeniu obszaru stabilności i przewidywalności w Europie" ${ }^{24}$. Sugestia spotkała się ze zrozumieniem i przychylnością współrozmówców, powtórzonymi następnie na początku 1993 r. przez Sekretarza Generalnego NATO Manfreda Wörnera. Umożliwiło to, podobnie jak militarne zaangażowanie naszego kraju na terenie byłej Jugosławii (misja pokojowa UNPROFOR), podpisanie przez Polskę w 1994 r. Partnerstwa dla Pokoju, jako ważnego etapu na drodze do członkostwa w NATO, zakończonego ostatecznie jej przystapieniem w $1999 \mathrm{r}$.

Równocześnie, pod koniec 1992 r., wobec niestabilnej sytuacji w Europie, specjalny zespół powołany przez prezydenta Lecha Wałęsę przy Radzie Bezpieczeństwa Narodowego, przygotował ramowe dokumenty, dotyczace bezpieczeństwa kraju, tj. Założenia polskiej polityki bezpieczeństwa oraz Politykę bezpieczeństwa $i$ strategie obronna Rzeczypospolitej Polskiej. Istotne $\mathrm{z}$ punktu widzenia tematu zapisy dotyczyły m.in.: „respektowania nienaruszalności istniejących w Europie granic; rezygnacji z roszczeń terytorialnych, poszanowania suwerenności, nieingerencji w sprawy wewnętrzne, wyrzeczenia się użycia siły lub groźby użycia siły; [...] budowania takiego systemu zbiorowego bezpieczeństwa, który

${ }^{22}$ K. Skubiszewski, Stosunki między Polskq i NATO w latach 1989-1993 - przyczynek do historii dyplomacji w III Rzeczypospolitej, http://www.liill.pl/1221451201,KrzysztofSkubiszewski-Stosunki-miedzy-Polska-i-NA.htm (dostęp 5 XII 2011).

${ }^{23}$ Tamże.

${ }^{24}$ Tamże. 
obejmowałby Europę i Amerykę Północna; [...] opracowania i przyjęcia przez wszystkie państwa modelu niekonfrontacyjnej doktryny militarnej, zakładającej zwiększanie bezpieczeństwa nie tylko danego kraju, ale również bezpieczeństwa innych, zwłaszcza sasiednich państw; [...] rozwijania idei tworzenia wielonarodowych sił zbrojnych i udziału w nich Polski; [...] tworzenia mieszanych jednostek wojskowych wspólnie z naszymi sąsiadami; [...] kierowania oddziałów Wojska Polskiego do udziału w Siłach Pokojowych ONZ lub do działania w innych misjach ONZ, KBWE, NATO, Północnoatlantyckiej Rady Współpracy lub Unii Zachodnioeuropejskiej”25. Przyjęcie powyższych dokumentów, pomimo niedoskonałości, należy uznać za duże osiagnięcie władz polskich. W omawianym bowiem czasie miał miejsce poważny konflikt na linii prezydent - rząd (z wyłaczeniem gabinetu Hanny Suchockiej). Dotyczył on tzw. ministerstw siłowych (Ministerstwa Spraw Zagranicznych, Ministerstwa Obrony Narodowej i Ministerstwa Spraw Wewnętrznych), tzn. sporu wokół ich obsady, kontroli i w konsekwencji ostatecznego podejmowania decyzji $\mathrm{w}$ ramach posiadanych przez nie kompetencji ${ }^{26}$. Konflikt widoczny był zwłaszcza w odniesieniu do Ministerstwa Obrony Narodowej, przed podpisaniem Partnerstwa dla Pokoju, czy też podjęciem decyzji o przedłużeniu mandatu polskich sił na terenie byłej Jugosławii.

Konflikt na Bałkanach doprowadził do katastrofy humanitarnej, której przejawem były tysiące uchodźców, poszukujacych schronienia w innych krajach. Polska, obok pomocy dla ludności przebywającej na obszarze walk, zdecydowała się przyjąć uciekinierów. W związku z powyższym, Sejm uchwalił w dniu 26 listopada 1992 r. apel do obywateli, w którym nawoływał do „moralnego, organizacyjnego i materialnego wsparcia działań Rządu, mających na celu udzielenie w Polsce schronienia uchodźcom z byłej Jugosławii, zwłaszcza z Bośni i Hercegowiny"27. Apel spotkał się z szerokim odzewem m.in. dzięki raportom T. Mazowieckiego. Działalność byłego premiera miała jednak głębsze reperkusje, wbrew jego własnym odczuciom, że to, co robi, „nie budzi w Polsce szerszego zainteresowania"28, ponieważ zwróciła uwagę władz na kwestię uchodźców, praw mniejszości narodowych i etnicznych w Polsce, jak również na problematyke praw człowieka. Ogromną rolę w tym zakresie odegrał Sejm I i II kadencji. W latach 1992-1995 Biuro Analiz Sejmowych przygotowało jedenaście „Materiałów i Dokumentów” oraz „Raportów” poświęconych wyżej wspomnianej problematyce. Zdzisław Galicki w Prawno-międzynarodowej ochronie uchodźców a polskim prawie wewnętrznym (grudzień 1994) przypomniał, że w Polsce działa na mocy

25 Założenia polskiej polityki bezpieczeństwa oraz Polityka bezpieczeństwa i strategia obronna Rzeczypospolitej Polskiej, s. 10, http://www.koziej.pl/files/ Strategia_RP_z_92_r.doc (dostęp 5 XII 2011).

${ }_{26}$ R. Podgórzańska, dz. cyt., s. 57, 59, 61.

${ }_{27}$ Apel Sejmu Rzeczypospolitej Polskiej z dnia 26 listopada 1992 r. w sprawie przyjecia uchodźców z dawnej Jugosławii, „Monitor Polski” 1992, nr 39, poz. 287, s. 447.

28 T. Mazowiecki, dz. cyt., s. 23. 
zarządzenia nr 60 Prezesa Rady Ministrów z 22 listopada 1990 r. Międzyresortowa Komisja ds. Uchodźców. Przewodniczy jej Pełnomocnik Ministra Spraw Wewnętrznych ds. Uchodźców ${ }^{29}$. Ponadto od 1 grudnia 1990 r. rozpoczęło działalność Biuro Pełnomocnika MSW ds. Uchodźców, obsługujące Pełnomocnika i wyżej wymieniona międzyresortowa komisję. Od lutego 1992 r. Biuro współpracowało z otworzonym w Warszawie Biurem Łącznikowym Wysokiego Komisarza Narodów Zjednoczonych ds. Uchodźców. Zarządzeniem nr 41 Ministra Spraw Wewnętrznych z 3 kwietnia 1992 r. powołano do życia jednostkę budżetowa „Ośrodek dla Uchodźców w Nadarzynie”, bezpośrednio opiekujący się uchodźca$\mathrm{mi}^{30}$. Autor analizy zwracał uwage na niedoskonałości uregulowań prawnych w odniesieniu do „uchodźców wojennych” z byłej Jugosławii, których nie obowiązują Konwencja z 1951 r. oraz Protokół z 1967 r.: „Dochodzi do paradoksalnych sytuacji, gdzie odnośne władze polskie nakłaniają wręcz osoby przybywające z Jugosławii do wystapienia o nadanie statusu uchodźcy na podstawie Konwencji z 1951 r., co ułatwiałoby możliwość przyznania im odpowiedniej pomocy i ochrony”31. Równocześnie Z. Galicki oświadczał wprost, że „kraje zachodnie za wszelką cenę starają się uniknąć przyjęcia osób z byłej Jugosławii jako uchodźców konwencyjnych". Spośród autorów przygotowujących raporty o mniejszościach narodowych i etnicznych, obok Z. Galickiego, Marcina Mroza, na czoło niewątpliwie wysuwa się Sławomir Łodziński, twórca większości powstałych na ten temat prac, np.: Mniejszości narodowe $w$ Polsce $w$ świetle dokumentów publicystyki (styczeń 1993); Ochrona praw mniejszości narodowych w pracach Rady Europy, KBWE $i$ ONZ (grudzień 1993); Opinie i postawy mieszkańców Polski wobec migracji i cudzoziemców w świetle badań opinii publicznej (styczeń 2002); Polityka państwa polskiego wobec mniejszości narodowych w latach 19891993 na tle rozwiazań prawnych obowiazujacych $w$ państwach europejskich $i$ regulacji przygotowywanych w ramach prac Rady Europy (styczeń 1994) ${ }^{32}$. Zwracano w nich uwagę na takie kwestie, jak: szkolnictwo mniejszości narodowych, podwójne nazewnictwo miast, ulic, dostęp do mediów itp. Prace, jakie wtedy przygotowano, odegrały istotna rolę podczas dyskusji dotyczaccych przygotowywanej ustawy o cudzoziemcach (Ustawa o cudzoziemcach z 27 grudnia 1997 r.), jak również odpowiedniego zapisu o ochronie praw mniejszości narodowych w projekcie konstytucji (art. 35 Konstytucji Rzeczpospolitej Polskiej z 2 kwietnia 1997 r.). Zajęcie się przez władze problemem uchodźców, mniejszości narodowych i etnicznych zwróciło uwagę społeczeństwa, że wojna w Jugosławii dotyka pośrednio również naszego kraju, że to są również nasze problemy, przed którymi nie można uciec.

${ }_{29}$ Z. Galicki, Prawno-międzynarodowa ochrona uchodźców a polskie prawo wewnętrzne (grudzień 1994), s. 7, http://biurose.sejm.gov.pl/teksty_pdf_94/r-67.pdf (dostęp 5 XII 2011).

${ }^{30}$ Tamże, s. 8 .

${ }^{31}$ Tamże, s. 11.

${ }^{2}$ Zob. Raporty BAS, http:/biurose.sejm.gov.pl/r.htm (dostęp 5 XII 2011). 
Jugosławia kojarzyła się Polakom przed 1991 r. z wakacjami spędzanymi w Dalmacji, dobrze zaopatrzonymi domami towarowymi, otwartymi granicami, samorządnością i niespotykaną w PRL wolnością ${ }^{33}$. Wybuch wojny i rozpad SFRJ dla większości polskiego społeczeństwa był szokiem, ponieważ nie orientowało się ono w skomplikowanej strukturze narodowościowej, nie wiedziało o występujacych między republikami różnicach ekonomicznych i pogłębiającym się od lat 80. XX w. kryzysie gospodarczym i politycznym. Wiedza przeciętnego Polaka o Jugosławii była niewielka, a jej obraz zniekształcony ${ }^{34}$. Paradoksalnie, to wydarzenia lat 90. minionego wieku przyczyniły się do wzrostu zainteresowania i wiedzy na temat Bałkanów, przy czym - często jednostronne informacje Polacy czerpali z doniesień prasowych, telewizyjnych wiadomości, nie mając możliwości ich weryfikacji. Przyczyniło się to do utrwalenia negatywnego obrazu Bałkanów i ich mieszkańców na kolejne dziesięciolecia, po zakończeniu konfliktów.

Dowodza tego badania polskiej opinii publicznej prowadzone m.in. przez OBOP w latach 90. (wcześniej badania dotyczace sytuacji nie tylko Jugosławii, ale i Półwyspu Bałkańskiego nie były przeprowadzane) ${ }^{35}$. Pod względem zakresu, pytania w przeprowadzonych badaniach objęły kilka obszarów, bezpośrednio lub pośrednio związanych z konfliktem. Pytania bezpośrednie dotyczyły przyczyn wojny, możliwych sposobów jej zakończenia, pomocy humanitarnej dla ofiar, jak również działań podejmowanych, w związku z powyższym, przez polskie władze. Pytania pośrednie objęły ocenę stanu bezpieczeństwa państwa, pozycji Polski w świecie, współpracy międzynarodowej i w tym kontekście możliwości realizacji priorytetowych celów polskiej polityki zagranicznej, tj. przystapienia Polski do NATO i Unii Europejskiej.

Pierwsze badanie polskiej opinii publicznej bezpośrednio dotyczące wojny na terenie byłej Jugosławii zostało przeprowadzone przez OBOP w dniach 5-6 kwietnia 1993 r., czyli ponad rok po rozpoczęciu działań zbrojnych w Bośni i Hercegowinie ${ }^{36}$. Termin eksploracji może wskazywać na nikłe zainteresowanie polskiego społeczeństwa wojna. Biorac pod uwagę podstawowe cele tego typu badań, można wnioskować, że zaangażowanie polskich władz na tym terenie było minimalne, przynajmniej do $1993 \mathrm{r}$.

Potwierdzają to pytania zadane respondentom. Pierwsze dotyczyło przyczyn walk prowadzonych na terenie byłej Jugosławii. Tylko $13 \%$ badanych stwierdziło, że zna źródła konfliktów, 38\% orientowało się „mniej więcej”,

${ }^{33}$ B. Jelavich, Historia Bałkanów, t. II: Wiek XX, Kraków 2000, s. 407.

${ }^{34}$ Wpływ na arkadyjski obraz Jugosławii, w bloku państw „demokracji ludowej”, miała propaganda polityczna SFRJ.

${ }_{35}$ Świadczyć to może o niewielkim znaczeniu, jakie Jugosławia miała dla Polski. Oczywiście, obydwa kraje współpracowały na polu naukowo-kulturalnym, gospodarczym, ale zakres współdziałania miał charakter marginalny w porównaniu z państwami „demokracji ludowej” oraz Związkiem Radzieckim.

36 Wojna na terenie bytej Jugosławii, OBOP, Warszawa, kwiecień 1993. 
natomiast łącznie prawie połowa, tj. 49\% przyznawała się do niewiedzy. Spośród osób wykazujących znajomość genezy wojny, ponad połowa wskazała na konflikt narodowościowy, 1/3 na konflikt religijny, 1/4 chęć nowego podziału terytorialnego. Około 1/4 twierdziła, że jest ona spowodowana walką o władzę, obrona suwerenności republik. Zdania były więc podzielone ${ }^{37}$. Zabrakło uzupełniającego pytania o źródło informacji. Biorąc pod uwagę spectrum odpowiedzi, łącznie z „tłem rasowym”, można co najwyżej domniemywać, że wiedzę na ten temat respondenci czerpali głównie z mediów. Nie przeprowadzono jednak w przypadku wojny w Bośni i Hercegowinie odnośnego badania ${ }^{38}$.

Na pytanie dotyczące sposobu zakończenia wojny w byłej Jugosławii, podano jako możliwość zbrojną interwencję wojskową sił międzynarodowych pod auspicjami ONZ - 63\% badanych opowiedziało się za takim rozwiązaniem (31\% „zdecydowanie tak”, zaś $32 \%$ „raczej tak”), natomiast $20 \%$ było jej przeciwnych (13\% „raczej nie”, $7 \%$ „zdecydowanie nie”) ${ }^{39}$. Większość respondentów uważała, że do interwencji powinno dojść bez względu na zgodę walczących stron (42\%). $28 \%$ uzależniało ją od zgody większości lub co najmniej jednej ze stron konfliktu. Natomiast $14 \%$ badanych było absolutnie przeciwnych interwencji. Aż $16 \%$ nie miało na ten temat zdania ${ }^{40}$. Biorac pod uwagę wspomniany wcześniej brak wiedzy o konflikcie, wartości te budziły niepokój, który, jak się okazało, nie korespondował z możliwymi sposobami jego zakończenia. Były natomiast kompatybilne $\mathrm{z}$ poparciem dla decyzji rządu o wysłaniu ochotników Wojska Polskiego do sił zbrojnych ONZ, przebywających na terenie byłej Jugosławii. Aż $69 \%$ badanych poparło ten krok, $18 \%$ było przeciwnych, zaś $13 \%$ nie miało na ten temat zdania ${ }^{41}$. Ciekawe, że w pytaniach nie uwzględniono możliwości pokojowego rozwiązania konfliktu. Aczkolwiek było to zgodne z taktyką władz polskich, które jak wcześniej wspomniano, unikały oficjalnego poparcia dla tego typu działań, powątpiewając w skuteczność środków dyplomatycznych.

Odmiennie natomiast kształtowało się poparcie społeczne dla decyzji rządu o przyjmowaniu i pomocy finansowej dla uchodźców z byłej Jugosławii. Aż 49\% badanych przyjęłoby uciekinierów w wyjątkowych przypadkach, $29 \%$ chciało ograniczyć ich napływ, $15 \%$ odmówiłoby ich przyjęcia, a tylko $4 \%$ przyjęłoby wszystkich. Prawie połowa (48\%) uznała, że państwo powinno przeznaczyć środki na pomoc dla uchodźców, $36 \%$ sprzeciwiło się temu, a $16 \%$ nie miało zdania ${ }^{42}$. Wpływ na wyżej wykazane postawy miał niewątpliwie fakt, że państwo polskie

${ }^{37}$ Tamże, s. 2.

38 Takiego „błędu” nie popełniono w późniejszym czasie, kiedy doszło do interwencji zbrojnej NATO w Jugosławii w marcu 1999 r. - zob. Kosowo - wojna $w$ mediach $i$ opinii publicznej, OBOP, Warszawa, maj 1999.

39 Wojna na terenie..., s. 2.

40 Tamize, s. 4.

41 Tamże, s. 5.

42 Tamze, s. 8 . 
w I połowie lat 90. XX w., po raz pierwszy od czasów II wojny światowej, borykało się z falą imigrantów nie tylko z byłej Jugosławii, ale też z byłych republik radzieckich. W poszukiwaniu spokoju, lepszych warunków życia przybywali oni do Polski, często traktując nasz kraj jako tranzytowy w drodze na Zachód. Ze względu na swa odmienność (wygląd, język, sposób zachowania) byli widoczni na ulicach, szczególnie dużych miast. Budzili niepokój, wręcz niechęć. Wyraźnie widoczny był tutaj brak tolerancji, której deklaratywnie Polacy chcieli się nauczyć jeszcze w 1992 r. Wtedy to, podczas badania przeprowadzonego 6-7 kwietnia, na pytanie: „Co powinniśmy przejać od społeczeństwa amerykańskiego?” - $25 \%$ ankietowanych odpowiedziało: „tolerancję - umiejętność współżycia z ludźmi innych narodowości, wyznañ”, zaś 22\%: „szczerość, otwartość w kontaktach z innymi ludźmi” 43 .

Ambiwalencja opinii publicznej dała o sobie znać po raz kolejny, kiedy bośniaccy Serbowie 26 maja 1995 r., w odwecie za naloty NATO na obiekty strategiczne, wzięli jako zakładników obserwatorów ONZ i żołnierzy misji pokojowej. Wśród nich znaleźli się dwaj polscy oficerowie. Przeprowadzone badania (5-6 czerwca 1995 r.) wykazały, że 73\% ankietowanych opowiedziało się za ich uwolnieniem w drodze negocjacji i rozmów ( $2 \%$ optowało za czekaniem; $9 \%$ nie miało zdania na ten temat) ${ }^{44}$. Tylko $16 \%$ zdecydowanych było na akcję zbrojną ${ }^{45}$, pomimo tego, że we wcześniej omawianym badaniu ponad połowa (63\%) optowała za siłowymi rozwiązaniami na terenie Bośni ${ }^{46}$. Natomiast wśród powodów, dla których polscy żołnierze zdecydowali się na służbę w misji pokojowej na terenie Jugosławii, respondenci podali motywy finansowe (60\%), chęć przeżycia przygody (23\%), chęć wykazania się odwaga $(19 \%)^{47}$. Wskazywały one, że według Polaków, polscy żołnierze mieli świadomość zagrożenia i konsekwencji służby na terenie Bałkanów.

Wojna na terenie Bośni i Hercegowiny wpłynęła pośrednio na percepcję przez polską opinię publiczną spraw bezpieczeństwa państwa, pozycji Polski w świecie, współpracy międzynarodowej i kierunków jej rozwoju. Choć należy podkreślić, że konflikty na Bałkanach były traktowane instrumentalnie, raczej w kontekście ustosunkowania się do nich naszych sąsiadów: Niemiec i Federacji Rosyjskiej oraz niebezpieczeństwa powtórzenia się scenariusza jugosłowiańskiego w Europie Wschodniej, to zwróciły uwagę na kluczowe problemy zwiąane z funkcjonowaniem państwa w nowych warunkach i wywołały publiczną dyskusję na ten temat.

${ }^{43}$ O stosunkach międzynarodowych, OBOP, Warszawa, kwiecień 1992, s. 3.

${ }^{44}$ Opinie o sprawie polskich zakładników w Bośni i udziale polskich żotnierzy w misjach zagranicznych, OBOP, Warszawa, czerwiec 1995, s. 5.

${ }_{45}$ Tamże.

${ }^{46}$ Wojna na terenie..., s. 3.

${ }_{47}$ Tamże, s. 6. 
W badaniach opinii publicznej ocena stanu bezpieczeństwa państwa w latach 90. ulegała widocznemu wahaniu. Przed wybuchem wojny na terenie byłej Jugosławii, tj. 3-4 kwietnia 1991 r., 16\% ankietowanych dostrzegało zagrożenie wojna ${ }^{48}$. Natomiast po wybuchu wojny w Bośni i Hercegowinie, poczucie zagrożenia wzrosło. Według badania z 24-25 marca 1992 r. 36\% badanych uznało, że istnieje zagrożenie wojenne dla naszego kraju, wobec $55 \%$ twierdzących, że takiego zagrożenia nie ma ${ }^{49}$. Co ciekawe, 25-26 października $1993 \mathrm{r}$. „tylko” 19\% respondentów zauważyło niebezpieczeństwo potencjalnej agresji na Polskę do 2000 r., 57\% zaś nie ${ }^{50}$. Gdyby bezpieczeństwo państwa oceniać tylko stopniem zagrożenia wojna, to w oparciu o powyższe dane można stwierdzić, że Polacy czuli się, w porównaniu do lat poprzednich, bezpiecznie. Konflikt na Bałkanach nie miał większego wpływu na te odczucia. Jednakże badanie z października 1993 r. przeczy temu. Respondenci stwierdzili w nim, że sytuacja międzynarodowa z punktu widzenia interesów Polski jest niekorzystna. Doszło na tym polu do inwersji: w 1991 r. 49\% badanych uznało, że uwarunkowania międzynarodowe są korzystne dla Polski, przy $37 \%$ przeciwnych tej opinii ${ }^{51}$. Natomiast w 1993 r. 34\% ankietowanych stwierdziło, iz sytuacja jest korzystna, zaś $49 \%$ było odmiennego zdania ${ }^{52}$. Kluczowe okazało się pytanie, co uczyniłby Zachód w przypadku próby pozbawienia Polski suwerenności przez Rosję lub przez inne państwo WNP? Aż 56\% ankietowanych stwierdziło, że Zachód nie stanąłby w naszej obronie (w 1991 r. 31\%), przy 20\% uważających, że zrobiłby to (w 1991 r. 45\%) ${ }^{53}$. Polacy uznali, że nie należąca do zachodnioeuropejskich struktur Polska nie może liczyć na pomoc Zachodu, a wojny na Bałkanach dowiodły, ile warte jest zaangażowanie dyplomatyczne organizacji międzynarodowych, przy równoczesnej dezaprobacie Rosji dla kolejno podejmowanych działań. Konflikty w byłej Jugosławii uświadomiły Polakom, że nasz kraj nie byłby w stanie samodzielnie oprzeć się potencjalnemu zagrożeniu.

Potwierdziło to badanie przeprowadzone w dniach 18-22 listopada $1994 \mathrm{r}$. nt. „Czy polskie siły zbrojne zapewniaja bezpieczeństwo kraju?”. Aż 64\% ankietowanych uznało, że polskie wojsko nie zapewnia w wystarczajacym stopniu bezpieczeństwa kraju (3\% uważało, że „zdecydowanie tak”, 20\% „raczej tak”, a $13 \%$ nie miało zdania) ${ }^{54}$. Wśród głównych powodów podano: słabe wyposażenie armii (83\%), spory polityków o kontrolę nad armią (56\%), słabość państwa (34\%),

${ }^{48}$ Opinie o bezpieczeństwie Polski, OBOP, Warszawa, kwiecień 1991, s. 1.

${ }^{49}$ Opinie o sprawach międzynarodowych, OBOP, Warszawa, marzec 1992, s. 1.

${ }^{50}$ O sprawach miedzynarodowych, OBOP, Warszawa, listopad 1993, s. 1.

${ }^{51}$ Opinie o bezpieczeństwie..., s. 1.

52 Tamże.

${ }^{53}$ Tamże, s. 2.

${ }^{54}$ Czy polskie sity zbrojne zapewniaja bezpieczeństwo kraju?, OBOP, Warszawa, grudzień 1994, s. 2. 
nieprzynależność do sojuszy wojskowych $(27 \%)^{55}$. Społeczna ocena polskiej armii systematycznie ulegała obniżeniu. W marcu 1992 r. 59\% badanych wskazywało na słabość wojska ${ }^{56}$, w 1991 r. tylko $32 \%{ }^{57}$.

Remedium na zmienione warunki międzynarodowe miała być integracja Polski ze strukturami zachodnioeuropejskimi. W 1993 r. społeczeństwo polskie już zdecydowanie popierało dążenia władz zmierzające do członkostwa we Wspólnocie Europejskiej (85\%) i NATO (81\%). Z punktu widzenia polskiej racji stanu był to niewątpliwie najważniejszy skutek pośredni ówczesnej sytuacji w Europie, w tym toczących się na Bałkanach konfliktów.

Podpisanie porozumienia pokojowego z Dayton w 1995 r., pomimo ewidentnej niedoskonałości, wszyscy (może z wyjątkiem najbardziej zainteresowanych) przyjęli z ulga. Zakończyło ono bowiem najkrwawszą i najdłuższą po 1945 r. wojnę w Europie. Dla państwa polskiego i społeczeństwa była ona o tyle ważna, że przyczyniła się do realizacji nadrzędnych celów polskiej polityki zagranicznej (uczestnictwo w Partnerstwie dla Pokoju, wzrost znaczenia i prestiżu na arenie międzynarodowej i w regionie) oraz uświadomiła, że przynależność do Europy wiąże się nie tylko z określonymi profitami, ale również z uciążliwymi obowiązkami (o charakterze finansowym, militarnym) i odpowiedzialnością nie tylko za siebie, swój naród i kraj, ale też za całą wspólnotę.

W chwili wybuchu wojen na terenie byłej Jugosławii, szczególnie krwawego konfliktu w Bośni i Hercegowinie, polskie władze stanęły przed wyborem kierunku dalszego rozwoju. Wojna na odległych krańcach Europy przyspieszyła podjęcie decyzji o integracji ze strukturami zachodnioeuropejskimi. Wstępnie, dzięki zaangażowaniu polskich sił na terenie objętym działaniami zbrojnymi, uwierzytelniła nasze państwo w oczach potencjalnych sojuszników i partnerów. Uświadomiła również, że przynależność do Europy wiąże się przede wszystkim z obciążeniami i obowiązkami. Wpłynęła na podjęcie wewnątrzpaństwowej dyskusji o problemach, zarówno politycznych, jak i społecznych, doprowadzając w dalszej perspektywie do ich rozwiąania. Dała społeczeństwu polskiemu, obok wiedzy na temat obszaru byłej Jugosławii, świadomość wpływu na postanowienia decydentów. Można pokusić się o stwierdzenie, że w tym aspekcie była krokiem na drodze do kształtowania się podstaw społeczeństwa obywatelskiego i nowoczesnego państwa.

55 Tamíe, s. 3.

56 Opinie o sprawach międzynarodowych..., s. 2.

${ }^{57}$ Opinie o bezpieczeństwie..., s. 5. Poprawie uległo natomiast porównanie polskich sił zbrojnych z wojskami niemieckimi i rosyjskimi. Generalnie uważano jednak, że Polska dysponuje słabsza armia. 